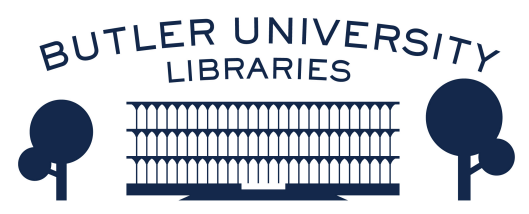

Journal of Hindu-Christian Studies

Volume 9

Article 15

January 1996

\title{
Book Review: "Practice and Theology of Interreligious Dialogue. A Critical Study of the Indian Christian Attempts Since Vatican II"
}

Anand Amaladass

Follow this and additional works at: https://digitalcommons.butler.edu/jhcs

Part of the Religion Commons

\section{Recommended Citation}

Amaladass, Anand (1996) "Book Review: "Practice and Theology of Interreligious Dialogue. A Critical Study of the Indian Christian Attempts Since Vatican II"," Journal of Hindu-Christian Studies: Vol. 9, Article 15.

Available at: https://doi.org/10.7825/2164-6279.1137

The Journal of Hindu-Christian Studies is a publication of the Society for Hindu-Christian Studies. The digital version is made available by Digital Commons @ Butler University. For questions about the Journal or the Society, please contact cbauman@butler.edu. For more information about Digital Commons @ Butler University, please contact digitalscholarship@butler.edu. 
and hymns (stotra). It is laudable that the editors have left out the more offensive apologetic passages which would defeat the purpose of such an anthology, and which instead of serving as a bridge between the Hindu and Christian traditions, would lead back into a bygone theological era of mutual condemnation.

While congratulating the authors on their thorough and at the same time poetic work, one hopes that this book will not remain stacked away in research libraries. One hopes that it will have a living impact in the following ways: 1) The Christians in India could use these texts as prayers and hymns and thereby imbibe the depth and beauty of Sanskrit expressions of their faith; 2) These Sanskrit compositions, even though they were to a great extent apologetical in their approach, should and could contribute to a dialogue between Hindus and Christians, Sanskrit being the privileged medium, at least in its terminology and religiousphilosophical associations; 3) Present-day theologians, in India, but in other parts of Asia as well, should reflect on the theological implications and on the rich potential of Sanskrit. Even W. H. Mill was, in his time, convinced that what could be done with Greek. for the Christian faith could also be done with Sanskrit" (p. XIII). In our present-day context, theologians should realize that going back to Sanskrit does not mean a conservative attitude, but rather opens up doors of understanding between different religious traditions.

Bettina Bäumer

Varasani

\section{Practice and Theology of Interreligious Dialogue. A Critical Study of the Indian Christian Attempts Since Vatican II. Jose} Kuttianimattathil. Bangalore: Kristu Jyoti Publications, 1995, xxiii+757 pp.

THIS VOLUME WAS originally presented as a doctoral dissertation in the Faculty of the Pontifical Gregorian University in Rome. Fr Jacques Dupuis, who guided this research work, writes the foreword saying that this is an "impressive witness to the theological ferment that characterizes the Indian Church" on interreligious dialogue and the extensive bibliography (105 pages) is cited as ample evidence of this ferment.

The author himself points out the scope or "the limitations" of this study. First of all, it covers the period from the end of the Second Vatican Council (1965) to 1991 when the Roman Document on "Dialogue and Proclamation" appeared. Secondly, it leaves out the individual denominations, since they were too many, taking only the official position of the Church. Thirdly, it makes no attempt to give a comprehensive picture of the development in the theology of dialogue and it looks at specific problems of terminology and their significance from the Christian point of view.

The book is divided into four parts: 1) The beginning and progress of interreligious dialogue in India; 2) The collective thinking of the Indian churches on issues related to dialogue; 3) Responses of Indian Christian theologians to the major issues on dialogue; 4) Overall assessment and prospects.

It is certainly an impressive and welldocumented source book on interreligious dialogue. It is especially interesting to read the history of the debate on the uniqueness of Christ. Different Indian theologians are grouped under different models of Christology like the rigid-uniqueness models, Christocentric models, pluralistic models, and so on, along with a critique of 
these models. Sometimes one wonders whether the terminologies used by the thinker to convey the mystery that is expounded is adequately understood from the author's point of view. The language of the critique from the traditional position does not meet the challenge that is proposed. For instance, the cosmotheandric mystery that Panikkar talks about with reference to Phil.2.9 is dismissed as "exegetical machiavellism". The theocentric approach of Samartha, Puthiadam, and others are opposed to Christocentrism, and so on. One gets the impression that the loyalty to the traditional thinking and its formulation dominates the scene, leaving aside the mystery that is being contemplated. This is not necessarily loyalty to the faith in Jesus Christ but very often is a sign of inability to look beyond the traditional framework. Thus this approach does not highlight sufficiently the process brought about by the ferment of fresh thinking in the Indian Church.

Secondly, the whole discussion is presented as Asian contribution, but the tone and language are of the thinking within the
Christian traditions without sufficient reference to other religious traditions in Asia. Practice of dialogue has to grow yet to reach that level, because the dialogue is restricted to Christian thinkers from within their framework without sufficient exposure to the theologies of other religious communities. Such exposure would change the language. The author himself concludes that interreligious dialogue presupposes a theology of religion. And the field of the theology of religions is still greatly unexplored (p.394). In the concluding section the elements of the emerging theology of dialogue are summed up with its future prospects.

But this volume is well documented and is a helpful source to identify different thinkers who have written on dialogue. Any library will be eager to have a copy of it as ready reference on matters relating to the discussion on interreligious dialogue in India.

Anand Amaladass, S.J. Madras

\section{Swami Abhishiktananda: His Life Told Through His Letters. James Stuart. Delhi: ISPCK, 1995, xvi+348 pp.}

\section{THE BIOGRAPHY OF Swami} Abhishiktananda, the French monk Henri le Saux (1910-1973), is presented as an autobiography letting the man speak through his letters written to his friends. Abhishiktananda was in India for 25 years (1948-1973) trying to live up to an ideal, a mission he set for himself, to realize the truth of advaita, as he understood it to be the core of the Upanisads and the search of the Hindu saints. Remaining "viscerally" Christian, he explored the possibility of harmonizing Hindu and Christian experience.

Abhishiktananda is known to many through his books and some of them have. been translated into different languages. The man behind these writings is revealed through this book. This was first published in 1989 and the revised version of it, which is now under review, appeared in 1995 . The volume is made possible by the many admirers who preserved his letters and shared their recollection of him. The author of this book has done a marvellous work in weaving together letters of this great man in such a way that the readers discover the man and his spiritual journey through these pages without even being aware of the biographer's presence.

Church history in India is recorded in and through personalities like 